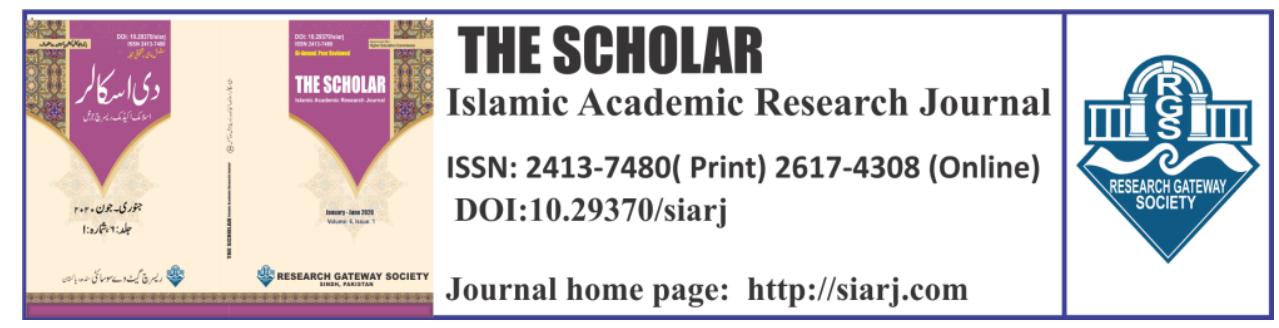

\title{
A COMPARATIVE STUDY OF VARIANCES IN THE NATURE OF HUMAN DISPOSITION IN GHAZALIAN THEORY OF SOUL AND FREUDIAN PSYCHOANALYSIS
}

\section{Shumaila Mazhar}

Assistant Professor, Department of English, Sardar Bahadur Khan Women University Quetta

Email: shumylaadnan786@gmail.com ORCIID IID:

https://orcid.org/0000-0001-8922-7671

\section{Gulnaz Naeem}

Assistant Professor, Department of Islamic Studies, Benazir Bhutto Shaheed University Karachi

Email: gulnaz.naeem@bbsul.edu.pk ORCID IID:

https://orcid.org/0000-0002-6322-0321

\section{Shabana Akhtar}

Assistant Professor, Department of Pakistan Studies, Sardar Bahadur Khan Women University Quetta, Pakistan Email: Shabanaakhtar@gmail.com ORCID ID:

https://orcid.org/0000-0003-3262-6406

To cite this article:

Mazhar, Shumaila, Gulnaz Naeem, and Shabana Akhtar. "-A COMPARATIVE STUDY OF VARIANCES IN THE NATURE OF HUMAN DISPOSITION IN GHAZALIAN THEORY OF SOUL AND FREUDIAN PSYCHOANALYSIS." The Scholar-Islamic Academic Research Journal 6, No. 1 (May 31, 2020): 252-276.

To link to this article: https://doi.org/10.29370/siarj/issue10ar18

\begin{tabular}{|c|c|}
\hline Journal & The Scholar Islamic Academic Research Journal \\
\hline Publisher & $\begin{array}{l}\text { Vol. 6, No. } 1 \text { || January -June } 2020 \text { || P. 252-276 } \\
\text { Research Gateway Society }\end{array}$ \\
\hline DOI: & 10.29370/siari/issue10ar18 \\
\hline URL: & https://doi.org/10.29370/siarj/issue10ar18 \\
\hline License: & Copyright c 2017 NC-SA 4.0 \\
\hline Journal homepage & www.siarj.com \\
\hline Published online: & $2020-05-31$ \\
\hline
\end{tabular}
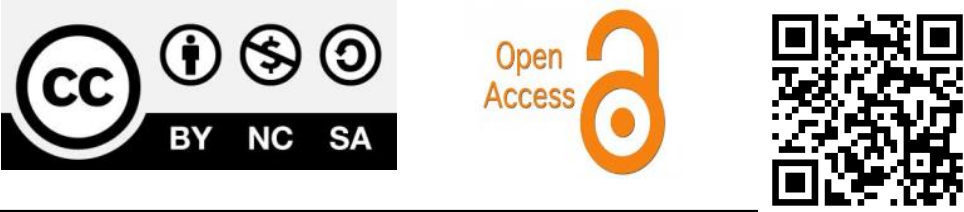
THE SCHOLAR (January- June 2020)

\title{
A COMPARATIVE STUDY OF VARIANCES IN THE NATURE OF HUMAN DISPOSITION IN GHAZALIAN THEORY OF SOUL AND FREUDIAN PSYCHOANALYSIS
}

\author{
Shumaila Mazhar, Gulnaz Naeem, Shabana Akhtar
}

\begin{abstract}
:
The present study aims at providing the venue to the mystical insights of Ghazalian theory of soul to be integrated into the study of Freudian psychoanalysis, with its principal emphasis on the variances between them. Moreover, the foundational belief of this research proceeds from the assumption that although Freudian psychoanalytic theory has enriched the world with its insightful psychological interpretations, correspondingly appropriate appraisals result from analyzing Ghazalian theory of soul. This study adopts the descriptive and analytic methodology to investigate the variances in both the models and has been developed according to the guidelines provided by Zepetnek's (1998) theory of comparative literature. The findings of the study reveal that despite certain profound similarities in Ghazlain theory of soul and Freudian psychoanalysis, there exist some variances arising out of specific settings and distinct frames of reference in which these theories are produced. This analytical approach may lead to an alternative critical agenda for the better understanding of human mind.
\end{abstract}

KEYWORDS: Psychoanalysis, Human nature, conscious, spirituality, instinct 


\section{INTRODUCTION}

Since time immemorial, human mind has been a focus of perpetual interest of a vast array of intellectuals, philosophers, mystics and psychologists who have struggled to interpret it. The enormously multifaceted phenomenon in human beings is nature, which can be approached through several ways. In recent times, a great interest has been revealed in the critical analysis of the Western ideology about life which studies human being in a highly-categorized manner, considering him primarily as a material being. In order to get a profounder and thorough cognizance of human nature, Western psychological models have inclined to lay emphasis only on self, emphasizing more on the biological and psychical dimensions of an individual, sometimes ignoring the metaphysical side of human nature ${ }^{1}$. Resultantly, the spiritual being in man is either less acknowledged or just dismissed completely. For this reason, several attempts have been made by social scientists who recognize the want to comprehend personality and human psychology from a universal perspective, concluding that the divine constituent of human being is too dynamic to ignore as far as human psychological and temperamental studies are concerned ${ }^{2}$.

In brief, this entire development has increased our knowledge about what religion articulates about human psyche, its origin and development. However, due to the assertion that religious ideology

\footnotetext{
${ }^{1}$ Mohammad Yasin, The Islamic Conception of Human Nature with special reference to the Development of an Islamic Psychology (University of Cape Town. 1986)

${ }^{2}$ Hisham Abu-Raiya, "Toward a systematic Qura'nic theory of personality" (Mental Health, Religion \& Culture, 2012, 15(3): 217-233.
} 
regarding human psyche lacks empirical substantiation, there still exists lesser interest in this area of study. Likewise, a huge treasure of religious teachings and understandings that have exercised a significant influence on the thoughts, behaviours and attitudes of innumerable generations of people, need to be considered worthy of attention while reviewing human psyche. Hence, spiritual frameworks, provided by leading religious scholars, should be given due consideration as a valid field of investigation.

Thus, the present study intends to provide the venue to the spiritual insights of Ghazalian theory of soul to be incorporated into the study of Freudian psychoanalysis since both the theorists have enriched the world with their innovative and pioneering ideas. Although, these Islamic and Western models offer somewhat similar attitude towards the inner workings of human mind, yet the major concern of the present study is to examine the variances in their philosophical underpinnings.

\section{THEORETICAL FRAMEWORK}

The fundamental premises on which the theoretical framework for the current study is built are the theories promulgated by Ghazali and Freud, whose ideas about the intricacies of human psyche are significantly related. If Western world seems to be enriched by Freudian psychoanalytic theories; there have been several approaches in the Eastern world that provide tremendous help in effective analysis of human personality. Amidst various well-known philosophers, Ghazali expounds his theory of soul which presents a distinguishing concept of human evolution and development. Since Ghazali's theory of soul is founded on the teachings of 
$\overline{\text { Quran }^{3} \text {, so it runs parallel to his conception of God. A significant feature }}$ of Ghazalian thought is its concept of the illumination of divine light within soul. Ghazali sees human nature in its "relation of unity with God, from whom it receives its inner light"4. Accordingly, in Ghazali, the detailed study of human behaviour requires a profound analysis of human soul. Ghazali, as a true knower of human psychology, embarked on the task of examining the real psychological nature of man and revealed the presence of two special propensities in human nature, one that provokes an individual in the direction of evil and the second propensity is divine and produces good qualities 5 . Because of the presence of these two inclinations, three potentialities direct human soul, namely; nafs $e$ ammara, nafs e lawwama and nafs e mutmainna. Ghazali explained their exact nature by asserting that if the inferior self or nafs e ammara grows stronger, it makes the divine features of soul subject to vice, which exercises harmful effect on human conduct. Contrariwise, if the heavenly elements of nafs al-lawwama become extremely mindful of God's existence, the evil elements produce virtue. In this way, devilish leaning is replaced with goodness which eventually ends in the peaceful state of mind or nafs e mutmainna 6 .

\footnotetext{
${ }^{3}$ Hisham Abu-Raiya, "Toward a systematic Qura'nic theory of personality" (Mental Health, Religion \& Culture, 2012, 15(3): 217-233. ${ }^{4}$ Harold, Coward, Jung and Eastern Thought. State University of New York Press, USA. 1985.

${ }^{5}$ Abu Hamid, Ghazali, Kimyâ-yı Saadet Kimiya-e Saadat-The Alchemy of Happiness. (The Other Press. 2000) ISBN 9839154958, 9789839154955. ${ }^{6}$ Abu Hamid Ghazali, Revival of Religious Learning. Ihya-ulum- Udin Book 3. Fazal-ul-Karim. Trans (Muhammad Ashraf, Lahore. 1993)
} 
Similarly, Freudian psychoanalytic discovery foreshadowed the foundation of modern psychology as one of the intellectual milestones of the $20^{\text {th }}$ century ${ }^{7}$. Freudian stance regarding human mind, encompassing its tripartite model - the $i d$, ego and superego - heralded certain new vistas of understanding and visions into modern psychology. Originally.it was through his highly-acclaimed work Interpretation of Dreams (1900), Freud offered his keen arguments on the presence of the unconscipartous, repressed underneath conscious. Following this, Freud extemporized his structural model coining terms like $i d$, ego and superego. For the first time he expounded his ideas in his essay Beyond the Pleasure Principle in 1920, illustrating that id,_ego and superego were not isolated areas that created divisions in human mind, rather they are theoretical concepts, unfolding several roles of human mind. In 1923, Freud brought forward an all-inclusive explanation on the working of human mind in his essay The Ego and the Id.

Freudian elucidation of $i d$ denotes to that dim and unapproachable part of human mind which encompasses rare forces and epitomizes fundamental drives, constituting the "biological and instinctual" part of human personality ${ }^{8}$. To gratify the elementary instincts under pleasure principle, id converts the biological needs into psychological tensions. When a child is born, these innermost forces remain unsocialized as they

${ }^{7}$ Schwartz, L. and Solomon, P, Psychoanalysis: Chapter 31, In Handbook of Psychiatry, P. Solomon and V. Patch (eds.) (Los Altos: Lange Medical Publications. 1974), 489-522.

${ }^{8} \mathrm{Jim}$ McMartin, Personality Psychology: A Student-Centered Approach (s8aQ2f New Delhi: SAGE Publications.1995) 


\section{Achieving the true purpose of education: role of current system of} education and Islamic viewpoint

have not been influenced by the exterior world ${ }^{9}$. The buried forces of id are motivated by the pleasure principle, which incline to attempt for the instant indulgence of its instincts "to live and reproduce" ${ }^{10}$. Id symbolizes forces which result in behaviour, normally considered destructive by the majority of a civilized population. ${ }^{11}$

Moreover, although Ego has multiple meanings depending on both theoretical and cultural contexts, but this study will use Freudian's descriptions only who views ego as a protective, intermediary shield between the $i d$ and the external world. This is the structure of personality that deals with the real world and has been literally termed as the "I"12. The demands of $i d$, which merely aim at pleasure gratification, get balanced through ego's attempts of providing appropriate satisfaction. Since $e g o$ works on reality principle and can endure burdens enforced by $i d$, it postpones the gratification of our instinctive drives till they can be appropriately satisfied. ${ }^{13}$

In addition, the entity which forces one to act according to the socially acceptable behaviour and supports him in shaping his personality, is labelled as superego. It is, to some extent, similar to the conscience which offers a set of guiding principles, instilling a sense of correct and

\footnotetext{
${ }^{9}$ Howard S. Friedman and, Miriam W. Schustack, Personality, Classic Theories and Modern Research (Allyn \& Bacon. USA. 1999)

${ }^{10}$ Mayers, Ozzie, The Power of the Pin: Sewing as an Act of Rootedness (American Literature. College English. 1988)

${ }^{11}$ Jack, Boozer, Religion, the Id, and the Superego. Journal of Bible and Religion (Oxford University Press. 1960), .3(28), 323-328

${ }^{12}$ Howard S. Friedman and, Miriam W. Schustack, Personality, Classic

Theories and Modern Research (Allyn \& Bacon. USA. 1999)

${ }^{13} \mathrm{Jim}$ McMartin, Personality Psychology: A Student-Centered Approachm (New Delhi: SAGE Publications.1995)
} 


\section{Achieving the true purpose of education: role of current system of}

education and Islamic viewpoint

incorrect, which grows with the integration of parental instructions. Further, certain parts of superego are unconscious because human beings are not always mindful of the enforced moral forces that restrain their conduct.

\section{LITERATURE REVIEW}

Theories of mind have long been a question of great interest in a wide range of literary fields. The issues regarding the intricacies of human mind have been raised and discussed by mighty intellectuals of all times. The frequent attempts intended to explore human psyche and mind reveal that it has been an essential concern in almost all ages. Moreover, to construct a better and more comprehensive view of human mind, according to LeDoux (2002), is "not to put the various theories in conflict with each other but rather to create a sense of harmony among them"14. Recent trends in interdisciplinary postulation between science and the humanities divulge that the knowledge about human mind can be enhanced, if seemingly discordant viewpoints are brought into dialogue. Thus, the current study is an attempt to explore the variances in the theories promulgated by Ghazali and Freud, the two mighty minds of the world.

Smith (1944) considers him among the first whose works fascinate the attention of European scholars. Moreover, Ghazali has also been "applauded as one of the greatest" 15 and "the most significant theorist of

${ }^{14}$ Joseph, LeDoux, Synaptic self: How our brains become who we are (New York: Penguin Books. 2002)

${ }^{15}$ W.Montgomery Watt, The Faith and Practice of Al Ghazali (One world Publications. England. 1953) 
Achieving the true purpose of education: role of current system of education and Islamic viewpoint

medieval Islam"16. Ghazali believes in the presence of two essential propensities in human soul ${ }^{17}$; the tendency towards vice (animalistic), and the tendency which stimulates a person towards virtuous deeds (angelic). These two peculiar tendencies ${ }^{18}$ produce three types of nafs, namely; nafs e ammara (the evil-instigating soul), nafs e lawwama (the rebuking soul), nafs e mutmainna (the contented soul). Moreover, Ghazali has also highlighted the role of $a q^{\prime} l$ in human psyche which plays the dynamic role of reason.

Turning now towards Sigmund Freud, the father of psychoanalysis, it has been found that his findings regarding unconscious and the development of the scientific inquiry of psychoanalysis, heralded a new era in modern psychology ${ }^{19}$. In the history of human civilization, Freudian theories regarding human mind have a huge impact in the realm of scientific, intellectual and cultural thought, despite the fact that many agree ${ }^{20}$ and some disagree ${ }^{21}$. Although the genuineness of Freudian metapsychology remains debatable, yet Freudian theory encompasses a huge corpus of

${ }^{16}$ F.R. Bagley, Introduction to Nasihat al Muluk, by Abu Hamid AlGhazali (NewYork and London: Oxford University Press. 1964)

${ }^{17}$ Hisham Abu-Raiya, "Toward a systematic Qura'nic theory of personality" Mental Health, Religion \& Culture, 2012), 15(3), 217-233

${ }^{18}$ Amber, Haque,"Psychology from Islamic perspective: Contributions of early Muslim scholars and challenges to contemporary Muslim

psychologists"(Journal of Religion \& Health. 43, 2004), 357-377

${ }^{19}$ Schwartz, L. and Solomon, P, Psychoanalysis: Chapter 31, In Handbook of Psychiatry, P. Solomon and V. Patch (eds.) (Los Altos: Lange Medical Publications. 1974), 489-522.

${ }^{20}$ Gerald Edelman, Bright Air, Brilliant Fire: On the Matter of The Mind (Basic Books. 1992) ISBN 0465007643, 9780465007646

${ }^{21}$ McCrone, J,Freud's neurology (Lancet Neurology, 2004), 3, 320 


\section{Achieving the true purpose of education: role of current system of} education and Islamic viewpoint

$\overline{\text { concepts which continues to exercise a deep impact on 20th century }{ }^{22} \text {. He }}$ has been considered as one of the greatest explorers of the human mind that ever lived ${ }^{23}$.

Freudian views on human mind, encircling its tripartite structures - the $i d$, ego and superego - innovate new perspectives of understanding and insights into modern psychology. However, despite this reputation of psychoanalysis, there remains a paucity of evidence on its scientific nature. More recently, literature has emerged that offers contradictory findings about psychoanalytic approach. As Eysenck, while providing an overview of Freudian psychoanalysis, states that this approach denotes a combination of scientific and non-scientific because Freud hardly ever gave "operational definition of his theoretical constructs of $i d$, ego and superego" so the final verdict might be given in favour of his approach being unscientific ${ }^{24}$.

The present study is based on the assumption that the spiritual insights of religion may offer distinctive potential to the field of psychological studies. At present, this can be perceived in such modernday movements such as transpersonal psychology, which directly integrates a divine element to psychotherapy. An evidence, in support of this argument, can be found in Washburn's discussion on the subject when

\footnotetext{
${ }^{22}$ Richard Askay and Jenson Farquhar, Apprehending the Inaccessible: Freudian Psychoanalysis and Existential phenomenology (Northwestern University Press, Evanston, Illinois. 200)

${ }^{23}$ Richard Askay and Jenson Farquhar, Apprehending the Inaccessible: Freudian Psychoanalysis and Existential phenomenology (Northwestern University Press, Evanston, Illinois. 200)

${ }^{24}$ Michael, Eysenck, Perspectives on Psychology (Psychology Press. Taylor and Francis Group, New York .2013), 112-113.
} 
The Scholar Islamic Academic Research Journal

Vol. 6, No. 1 || January-June 2020 || P. 252-276

https://doi.org/10.29370/siarj/issue10ar18

he mentions that psychoanalysis in its "skeptical denial of transcendence, has turned its back on the possibility of transcendence", while transpersonal psychology has an "enthusiasm for transcendence" 25 . Increasingly, in the west, there is a trend of incorporating the insights, beliefs and spiritual doctrines of non-western traditions, especially Buddhism and eastern philosophy, to the practice of modern psychology. Though the spiritual dimension finds least attention by the followers of modern psychology, yet the American Psychological Association identifies religious psychology as a separate area in modern psychology ${ }^{26}$. Foundational to this, is the drastic change in the whole scenario that the last two decades witnessed. Initially, Christian models were focused exclusively, but later on, a widespread interest has been felt in research studies highlighting Muslim ${ }^{27}$ and Hindu models ${ }^{28}$. As a result, it might safely be asserted that the new field of the psychology of religion has emerged as a genuine field of research ${ }^{29}$.

\section{METHOD OF COMPARATIVE STUDY}

${ }^{25}$ Washburn, M. Transpersonal Psychology in Psychoanalytic Perspective (State University of New York Press, Albany. 1994.

${ }^{26}$ Achoui, M. Human Nature from a Comparative Psychological

Perspective (The American Journal of Islamic Social Sciences. 1998), 15(4): 71-96

${ }^{27}$ Hisham Abu-Raiya, "Toward a systematic Qura'nic theory of personality" (Mental Health, Religion \& Culture, 2012), 15(3): 217-233

${ }^{28}$ Tarakeshwar, Nalini; Pargament, Kenneth I.; Mahoney, Annette,

Measures of Hindu pathways: Development and preliminary evidence of reliability and validity (Culture Diversity and Ethnic Minority Psychology. 2003), 9: 316-332.

${ }^{29}$ Ralph W. Hood, Jr., Peter C. Hill, and Bernard Spilka, The psychology of religion: An empirical approach (5th ed) (New York: Guilford Press, 2009) 
The Scholar Islamic Academic Research Journal

Vol. 6, No. 1 || January-June 2020 || P. 252-276

https://doi.org/10.29370/siarj/issue10ar18

This research study has been established according to the guidelines provided by Zepetnek's (1998) theory of comparative literature. As this study deals with the variances present in the theoretical models of Ghazali and Freud on the concept of human mind, thus, Zepetnek's theory proposes an essential structure to meet its requirements. Fundamentally after providing a detailed analysis of the nature of comparative literature, it sheds light on different principles to be observed for studying $\mathrm{it}^{30}$. The effective application of Zepetnek's method of thematic inclusion needs to be grounded on its being (1) goal-oriented, organized to achieve particular goals (2) reciprocal, given or shown by each of two sides or individuals to the other, (3) based on equal status of both participants, (4) comparative and not influential, no side can influence the other, and (5) both sides maintain their individuality" 31 . For the current study, these principles have been kept in mind while comparing Ghazali and Freud to discover certain variances, manifestly existing in their theories._Though these theorists belonged to different eras, cultures, languages and religions, they hold certain similar views on the points that define features of the human mind, its role and impact on human life. However, the differences found in their respective views are fundamentally based on their religious beliefs.

\section{DATA ANALYSIS}

${ }^{30}$ Tötösy de Zepetnek, Steven. "Comparative Literature: Theory, Method, Application." Library Series, CLCWeb: Comparative Literature and Culture (2011)

${ }^{31}$ Mohammad Yasin, The Islamic Conception of Human Nature with special reference to the Development of an Islamic Psychology (University of Cape Town. 1986) 
The Scholar Islamic Academic Research Journal

Vol. 6, No. 1 || January-June 2020 || P. 252-276

https://doi.org/10.29370/siarj/issue10ar18

Ghazali and Freud have enriched the world with their innovative and pioneering ideas. A close examination of their theories reveals prominent similarities in their "structural and topographic" 32 dimensions. Though the analysis of these resemblances is not strictly related to the objectives of this study, but since these insights emerged during research process and seem relevant to the theoretical framework, so they need to be incorporated.

Ghazalian masterpiece Ihya Ulum ud Din (The Revival of Religious Sciences) is widely recognized for his psychological understandings where he divides mind into three categories based on Quran: the first categorization is nafs e ammara which urges an individual to satisfy socially unacceptable longings and indulge in evil ${ }^{33}$; Freud identifies this concept of psyche as the $i d$ part of the human mind ${ }^{34}$. The second category is that of nafs e lawwama, which is the conscience that leads man towards vice or virtue; modern psychology calls it superego ${ }^{35}$. The third category is that of nafs e mutmainna, which is a self that reaches the ultimate peace ${ }^{36}$ : the current psychology being secular, utterly neglects this element of human mind. Moreover, Ghazali also ascribes the pivotal

${ }^{32}$ Mohammad Yasin, The Islamic Conception of Human Nature with special reference to the Development of an Islamic Psychology (University of Cape Town. 1986)

${ }^{33}$ Ansari Ahmed. Qur'anic concepts of human psyche (Editor Zafar Afaq Ansari), Islamabad: International Institute of Islamic Thought and Institute of Islamic Culture, (1992). ISBN 9694620031, 9789694620039 ${ }^{34} \mathrm{Jim}$ McMartin, Personality Psychology: A Student-Centered Approachm(New Delhi: SAGE Publications.1995)

${ }^{35}$ Howard S., Friedman, Miriam W. Schustack,"Personality, Classic Theories and Modern Research" (Allyn \& Bacon. USA, 1999).

${ }^{36}$ Abu Hamid, Ghazali. Kimyâ-yı Saadet Kimiya-e Saadat-The Alchemy of Happiness. (The Other Press. 2000) ISBN 9839154958, 9789839154955. 
The Scholar Islamic Academic Research Journal

Vol. 6, No. 1 || January-June 2020 || P. 252-276

https://doi.org/10.29370/siarj/issue10ar18

role to aq'l which is the rational domain of human psyche; Freudian paradigm of ego significantly bears a resemblance to it, highlighting the effective use of reason and intellect. Besides, both the theorists agree that human mind is prone to irrational, primitive behaviour, under the influence of nafs e ammara or $i d$, despite the existence of a neutralizing force, i.e., $a q ' l$ or ego. The conflicting forces of nafs e ammara or id and nafs $e$ lawwama or superego, operating on varying levels, cause psychological conflict and nervousness in their desire for mental peace. Above and beyond, both the models are dynamic which propose the existence of two conflicting forces in individuals, influencing their thought, emotion and behaviour $^{37}$.

Quite interestingly, at this juncture, the major question arises about these similarities found in the psychological content of Ghazalian theory and Freudian psychoanalysis. What might explicate the fact that the thoughts promulgated by Ghazali in the $11^{\text {th }}$ century are so similar to Freudian psychoanalysis of the $20^{\text {th }}$ century? Could the reason be that Freud was influenced by Ghazali? Or maybe these resemblances affirm to the mutual foundation of human knowledge. Although these concerns are much interesting, their answers lie beyond the limits of this study.

Nevertheless, the major concern of the present study is to examine certain fundamental variances in the philosophical underpinnings of the selected theorists. However, prior to discussing the variances in the theoretical foundations of both the theorists, it should be borne in mind that the radical variance in both the models lies in the fact that Freudian

\footnotetext{
${ }^{37}$ Irvin D. Yalom, Existential psychotherapy. New York: Basic Books. 1980.
} 
The Scholar Islamic Academic Research Journal

Vol. 6, No. 1 || January-June 2020 || P. 252-276

https://doi.org/10.29370/siarj/issue10ar18

model is characterized by a "nonspiritual, biological-evolutionary nature" which considers $i d$, the animal component of humans, as the strongest force of psyche, while Ghazali lays the foundation of his "psycho-spiritual structure" of human psyche on divine revelation ${ }^{38}$. This fundamental difference paves the way for all the ensuing discussion on the topic.

\section{VARIANCES IN THE THEORETICAL FOUNDATIONS}

The first striking difference between both the theories lies in the fact that Ghazalian theory of soul is built on certain established and sound foundations of Quranic concept of human mind, and his major contribution lies in his delineation of its potential psycho- spiritual structures, so it may safely be called "religious/spiritual/theological theory"39. Throughout his works, Ghazali emphasizes on the significant part played by the religious and moral experiences to access knowledge. With regard to the profound impact of Quranic revelation on Ghazli's philosophical outlook, Ghazalian structure and function of human mind is not complete, without an appropriate consideration of the Quranic purpose and meaning of human creation and present life ${ }^{40}$. While dealing with the issues regarding the complexities of human body and its intellectual and

\footnotetext{
${ }^{38}$ Hisham Abu-Raiya, “Toward a systematic Qura'nic theory of personality" Mental Health, Religion \& Culture, 2012), 15(3), 217-233

${ }^{39}$ Amber, Haque,"Psychology from Islamic perspective: Contributions of early Muslim scholars and challenges to contemporary Muslim psychologists"(Journal of Religion \& Health. 43, 2004), 357-377. Amber, Haque,"Psychology from Islamic perspective: Contributions of early Muslim scholars and challenges to contemporary Muslim psychologists"(Journal of Religion \& Health. 43, 2004), 357-377. ${ }^{40}$ Ralph W. Hood, Jr., Peter C. Hill, and Bernard Spilka, The psychology of religion: An empirical approach (5th ed) (New York: Guilford Press, 2009)
} 
The Scholar Islamic Academic Research Journal

Vol. 6, No. 1 || January-June 2020 || P. 252-276

https://doi.org/10.29370/siarj/issue10ar18

spiritual dimensions, he refers to the "holistic Quranic view of human nature" ${ }^{\text {41 }}$. Thus, it might be safely asserted that the fundamental underpinning of the Ghazalian theory is "creationism and the pivotal role of the divine-devil antinomy" 42 .

On the contrary, Freudian psychoanalysis primarily concerns itself with biological-evolutionary model. Stevenson and Huberman argue that Darwin's theory of evolution has exercised tremendous impact on Freudian thoughts as much as that he includes human beings as another species of animals and this belief has paved the way for some of the foundations of his advancement of psychoanalysis ${ }^{43}$. Moreover, Darwin's Evolutionary theory discards the idea of the existence of any creator and eliminates any ingrained and deep-rooted religious sentiment of divine or satanic influence on human psyche. Therefore, Freudian psychoanalysis offers no corresponding terminology for soul. His anti-religious attitude is widely-known, when in his famous work, Future of an Illusion, Freud (1989) formally divulged his belief in the non-existence of any integral religious sentiment in human psyche. He resolutely holds all the religious beliefs and practices as the result of the repression of instincts, intrapsychic trauma, and vulnerability. He considers religion merely a

\footnotetext{
${ }^{41}$ Harold,Coward, Jung and Eastern Thought. State University of New York Press, USA. 1985.

${ }^{42}$ Ibid

${ }^{43}$ Nooraini, Othman, "A Preface to the Islamic Personality Psychology. (International Journals of Psychological Studies, 2015), 8(1) : 23. ISSN 1918-7211 E-ISSN 1918-722X
} 
The Scholar Islamic Academic Research Journal

Vol. 6, No. 1 || January-June 2020 || P. 252-276

https://doi.org/10.29370/siarj/issue10ar18

"mass delusion",44. This attitude has greatly influenced his overall judgement of human beings and, as Roland observes, he fails to identify human personality in an integrated manner. Fundamentally, his entire focus revolves around the hidden impulses and intrapsychic conflicts residing within unconscious ${ }^{45}$.

\section{VARIANCES IN THE PORTRAYAL OF ALL- ENCOMPASSING CONCEPT OF HUMAN PSYCHE}

Another chief difference between Ghazalian and Freudian theories lies in their profundity of covering all the dimensions of human personality. Freud fails to capture all the features of human psyche and ignores human personality in a holistic manner, linking it to only sociocultural factors and communal associations $^{46}$. Similar views have been presented by Nobles (1973) and Paranjpe (2010) when they argue that Freud's central focus is on individual problems which are insufficient for communal or spiritual dimensions of human living. Freudian psychanalysis ignores the spiritual dimension of human personality, considering it in the realm of philosophy.

\footnotetext{
${ }^{44}$ Sigmund Freud, Group Psychology and the Analysis of the Ego. In Sigmund Freud's Civilization and its Discontents and Other Works. J. Strachey et al (eds.) (London: Penguin Books, 1985), 91-178.

${ }^{45}$ Robert N. Sollod, Christopher F. Monte, John P. Wilson. Beneath the mask: An introduction to theories of personality (8th ed.). 2009

${ }^{46}$ Jackson, Leslie C. The New Multiculturalism and Psychodynamic

Theory: Psychodynamic Psychotherapy with African American Women. In Psychotherapy with African-American Women: Innovations in Psychodynamic Perspectives and Practice, ed. Leslie Jackson and Beverly Greene. New York: The Guilford Press. 2000.
} 
The Scholar Islamic Academic Research Journal

Vol. 6, No. 1 || January-June 2020 || P. 252-276

https://doi.org/10.29370/siarj/issue10ar18

His fundamental concern is with physical, biological aspects only ${ }^{47}$. Commenting on this, Achoui suggests that in order to achieve a better understanding of human mind, an "interactive and integrative" approach is needed, which may bridge the gap in current psychological theories ${ }^{48}$.

On the contrary, Ghazali (1993) considers man as being gifted with two distinct qualities, body and soul, possessing the twofold nature, physical and spiritual. Thus, human being becomes a combination of closely interrelated spiritual and bodily forces. However, it is the soul that mechanizes the physical body to function, whereas, body plays the role of just a container, offering a very appropriate place for the soul to reside in and functions as a bridge between corporeal and spiritual domains. ${ }^{49}$

\section{VARIANCES IN THE INTERPRETATION OF SEXUAL INSTINCTS}

Another significant point of variance between Ghazali and Freud is the nature of importance given to the issue of sex. In Freudian model, sex instinct has been considered the most dominating force in human psyche. Qaiser (2000) calls Freud a "sex intoxicated psychologist", 50 while Salter (1963) criticizes him for even "sexualizing" soldiers' worry about death,

\footnotetext{
${ }^{47}$ Wade W. Nobles. African psychology: Towards its reclamation, reascension, an revitalization. Oakland, CA: Institute for the Advanced Study of Black Family Life and Culture.1986

${ }^{48}$ Achoui, M, Human Nature from a Comparative Psychological Perspective (The American Journal of Islamic Social Sciences. 1998), 15(4): 71-96

${ }^{49}$ Abu Hamid Ghazali, Revival of Religious Learning. Ihya-ulum- Udin Book 3. Fazal-ul-Karim. Trans (Muhammad Ashraf, Lahore. 1993)

${ }^{50}$ Nazir Qaiser. A Critique of Western Psychology and Psychotherapy and Iqbal's Approach. Iqbal Academy Pakistan; Sa'adat Art Press, Lahore.2000.
} 
The Scholar Islamic Academic Research Journal

Vol. 6, No. 1 || January-June 2020 || P. 252-276

https://doi.org/10.29370/siarj/issue10ar18

mother's worry about children and man's worry about failure. ${ }^{51}$ Similarly, even Freud's followers as Carl Jung (1875-1961), Alferd Adler (18701937) and Karen Horney (1885-1952) strongly criticize Freud for his excessive emphasis on sexuality. In addition, many researchers have attributed the western sexual revolution that occurred in the last fifty years, to Freudian polymorphous sexuality. The result of this sexual revolution, which has been revealed in the form of "homosexuality, lesbianism, pornography, nudism, etc." is the cause of rapid spread of sexually transmitted diseases. ${ }^{52}$

However, Ghazali (1993) considers sex as a tendency, energy of life which serves the nutrition and development of human body. ${ }^{53}$ Valerie and Hoffman-Ladd (1992) argue that in Ghazalian philosophy, human sexuality is potentially destructive force that needs to be controlled within marriage. ${ }^{54}$ Besides, since sexual desire has been imbued in men and women to secure the survival of humanity, Ghazali construes sex as entirely a mechanism to reproduction. Erected on this theological edifice, Ghazali provides a dignified and exalted purpose to sexual desire, which ultimately becomes something superior to the urge for erotic pleasure. For

\footnotetext{
${ }^{51}$ Salter Andrews. A Case against Psychoanalysis. The Citadel Press, New York. 1963.

${ }^{52}$ Malik Babikar Badri, The AIDS dilemma: A progeny of modernity. In Al-Attas, Sharifah Shifah (ed). Islam and challenge of modernity (pp. 123210). Kuala Lumpur: International Institute of Islamic Thought and Civilization. (1996).

${ }^{53}$ Abu Hamid, Ghazali, Kimyâ-yı Saadet Kimiya-e Saadat-The Alchemy of Happiness. (The Other Press. 2000) ISBN 9839154958, 9789839154955.

${ }^{54}$ Valerie J. Hoffman-Ladd. Mysticism and Sexuality in Sufi Thought and Life. Mystics Quarterly, Vol. 18, No. 3, pp. 82-93; Penn State University Press.1922.
} 
The Scholar Islamic Academic Research Journal

Vol. 6, No. 1 || January-June 2020 || P. 252-276

https://doi.org/10.29370/siarj/issue10ar18

this reason, humanity seems to participate in God's creation and sexual pleasure is reduced to being of slight value. As Farah (1984) mentions Ghazali as saying that "the pleasure which accompanies it [sex]—pleasure which would be unrivaled were it to last - is a harbinger of the promised pleasures in paradise". ${ }^{55}$ Moreover, Ghazali (1993) argues that sexual urge needs to be restrained and gratified properly through the institution of marriage which is the only mean of maintaining man's virtue and shielding him from moral degradation. Briefly speaking, Ghazalian views regarding sex, diverge widely from Freudian interpretation in his elaboration of when (marriage) and why (procreation) of sexuality. Commenting on this, McMartin (1995) explores that Ghazali emphasizes on a balance of material desire and desire for the hereafter; dealing with the former through marriage increases the possibility of the latter". 56 Thus, Ghazali acknowledges the paramount value of sex as a desired and natural activity and gives it a dignified status for its being the only mean of human survival.

\section{VARIANCES IN THE DESCRIPTION OF INTRINSIC NATURE OF GOOD}

\section{AND EVIL}

Another important variation between the two models lies in their difference in opinions regarding the intrinsic nature of good and evil. Exploring the attitude of Freudian psychology in relation to the innate nature of man, it is evident that he holds an exceedingly pessimistic

${ }^{55}$ S.M. Ghazanfar, The Economic Thought of Abu Hamid Al-Ghazali and St. Thomas Aquinas: Some Comparative Parallels and Links; History of Political Economy (Duke University Press. 1993)

${ }^{56}$ Abu Hamid Ghazali, "Revival of Religious Learning. Ihya-ulum- Udin Book 3”. (Fazal-ul-Karim. Trans., Muhammad Ashraf, Lahore.1993). 
The Scholar Islamic Academic Research Journal

Vol. 6, No. 1 || January-June 2020 || P. 252-276

https://doi.org/10.29370/siarj/issue10ar18

approach as he finds a little goodness in human beings. As Etzioni (1947) observes that fundamentally Freudian human nature is $i d$, having a strong "Hobbesian foundation", 57 it is ruled by the self-centered pleasure principle and the craving for sex; man's unsocialableness makes him an impulse-driven animal, violent, vicious, afraid of death, in search of unhampered sexual pleasure.

On the contrary, Ghazalian approach is an objective one, as he makes an in-depth analysis of various aspects of man's psyche, considering him neither all good nor all evil, always combating against his evil inclinations. According to Ghazalian theory, a man is never immune to evil and no matter how evil he may be, he cannot be completely deprived of good. There exist certain factors that lead him towards either vice or virtue, like education, environment, biology and personal values. Ghazali views man as an amalgam of angelic and satanic tendencies. Moreover, Ghazali believes in the notion that a child is born with the Fitrah (primordial nature, free from any tinge of $\sin$ ) which is an Arabic term that reveals certain positive dimensions of human nature. There is no place for any inherent evil of human nature as its negative representation as a source of evil and wickedness, is evidently discarded. A child is born in this world with the purity of soul, while human depravity is merely inadvertent and violation of his original nature. Religion plays its pivatol role to guide human nature to its eventual destination of eternal contentment. Besides, Ghazali also discards the dogma of the "Original Sin" as advocated by Freud.

\footnotetext{
${ }^{57}$ Amitai Etzioni. Human Nature and the Transforming. International Journal of Group Tensions. Vol. 4 No.3. Sage Publications, Inc. (1947).
} 
The Scholar Islamic Academic Research Journal

Vol. 6, No. 1 || January-June 2020 || P. 252-276

https://doi.org/10.29370/siarj/issue10ar18

Inherent in the idea of fitrah is the outlook that each child is born with an intrinsic inclination to worship God. Although he is born with Fitrah, yet he has a potential to evil stimuli which needs to be controlled and directed towards divinely inspired guidance. While Freud made certain important discoveries in his study of human nature and his overall contribution in the realm of psychology is great, however, there remains a need to encounter Freud's anti-religious overtones. Childhood, which should be seen as a period of innocence on the part of children, when they learn to explore and adapt themselves to the environment and others around them, has been smeared by Freud with immoral stories, rivalry and forbidden sexual wishes.

\section{VARIANCE IN THE FUNCTIONS OF AQ'L AND EGO}

Though Ghazalian $a q^{\prime} l$ and Freudian ego seems to be the same, yet, it is significant to note, that there is a difference concerning the functions that ego and $a q^{\prime} l$ serve. Freudian ego mediates between the external and internal forces to reach ultimate pleasure. In other words, ego's main function is to discipline id to gratify its chaotic demands in a socially acceptable and legitimate manner, just to maximize pleasure.

On the contrary, Ghazali (1995) offers the similar logic in his argument about the major function of $a q^{\prime} l$ to discipline nafs e ammara, but he differs as regards to its purpose which is to restrain the devilish elements of nafs $e$ ammara. Moreover, his argument takes another different stance when he asserts that $a q^{\prime} l$ has an inherent angelic element. Since angels are pure intellect so man's faculty of $a q^{\prime} l$, helps him in getting closer to God, enabling him to isolate himself from the Satanic influences. Based his insight on Ghazalian reading, Yasien (1996) analyses that $a q$ 'l plays the 
The Scholar Islamic Academic Research Journal

Vol. 6, No. 1 || January-June 2020 || P. 252-276

https://doi.org/10.29370/siarj/issue10ar18

most significant role in controlling the satanic forces within psyche, thus, guiding these forces through proper channels. He further adds that man's achievement of a state of harmony depends on $a q$ 'l's success in weakening the Satanic impact, eventually making it futile. ${ }^{58}$ Since Freud builds his whole edifice on the animal component of humans as the strongest force of psyche, he fails to delineate any spiritual element in the workings of ego.

\section{VARIANCES IN THE ACHIEVEMENT OF THE OPTIMAL STATE OF NAFS}

\section{E MUTMAINNA}

The most noticeable distinction among the approaches of both the theorists seems to be the overt importance given to nafs e mutmainna in Ghazalion theory. While Freud (2010) argues that human psyche achieves its optimal state when the rational ego drives the whole psyche, there exists no equivalent term as Ghazalian nafs e mutmainna, the highest state of psycho-spiritual development that culminates in the state of eventual calmness and serenity. ${ }^{59}$ As nafs achieves a successful control over its appetites and cravings, it develops into tranquility and serenity by becoming free of tension. However, in Freudian psychoanalysis, the unconscious is the abode of sexual desires like Oedipus complex, etc., having no place for the divine qualities. Guenon (2001) considers it "one of the serious misdeeds of psychoanalysis" (p.274).

\footnotetext{
${ }^{58}$ Mohammad Yasin, The Islamic Conception of Human Nature with special reference to the Development of an Islamic Psychology (University of Cape Town. 1986)

${ }^{59}$ Sigmund Freud, Group Psychology and the Analysis of the Ego. In Sigmund Freud's Civilization and its Discontents and Other Works. J. Strachey et al (eds.) (London: Penguin Books, 1985), 91-178.
} 
The Scholar Islamic Academic Research Journal

Vol. 6, No. 1 || January-June 2020 || P. 252-276

https://doi.org/10.29370/siarj/issue10ar18

Similarly, with regard to the negligence of spirituality in Freudian theory, Ayadin (2010) argues that since Freud strictly ignored the nafs $e$ mutmainna dimension of human psyche, thus, it becomes evident that the goal of modern psychology is not to guide people to spiritual heights, while, the final goal of Islam is to attain this dimension. ${ }^{60}$ Ghazali, himself, as he mentions in his autobiography, reaches that state after experiencing the truth from mystical path. Likewise, Iqbal (1954) maintains that "Modern psychology has not yet touched even the outer fringe of religious life, and is still far from the richness and variety of what is called religious experience". ${ }^{61}$

While concluding the whole argument, the above-analysis demonstrates that although there are many similarities between the psychic components of Ghazalian theory and Freudian tripartite model of Psychoanalysis, however, when it comes to the origin of these structures, they significantly diverge in some of their fundamental assumptions. Thus, in the Western theories of the self, it seems, that no one has reached the whole truth. LeDoux (2002) while exploring its reason, points out that it is not due to erroneous nature of various theories but because many of them are partially correct. If this is a true assumption then the best way to construct a view regarding self could be "not to pit the various theories against one another but rather to synthesize across them". ${ }^{62}$

\footnotetext{
${ }^{60}$ Hayati Aydin. Concept of the Self in Islamic Tradition and Western Psychology. Studies in Islam and the Middle East. (7)1, ISSN 155401.2001 .

${ }^{61}$ Mohammad Iqbal. The Reconstruction of religious thought in Islam. Sheikh Muhammad Ashraf, Lahore. 1954.

${ }^{62}$ Joseph LeDoux. Synaptic self: How our brains become who we are. New York: Penguin Books. 2002)
} 
The Scholar Islamic Academic Research Journal

Vol. 6, No. 1 || January-June 2020 || P. 252-276

https://doi.org/10.29370/siarj/issue10ar18

Existing trends in interdisciplinary postulation between science and the humanities verify the hypothesis held here, that not only can we act better in envisaging and knowing human nature, but the authenticity of human nature will become richer as we conjure up seemingly dissenting point of views into dialogue.

\section{RECOMMENDATIONS AND SUGGESTIONS}

Based on the findings of this research, the present study recommends the need for a diverse outlook which may contribute in better and all-inclusive understanding of human nature. Since the modern psychological disorders have led to a reawakening among psychologists to analyze human mind and personality by incorporating a spiritual component, so Ghazalian theory of soul had never been more meaningful to the world as to respond to the moral decay and value crisis of the present atheistic-materialistic globalization. However, Ghazali notion of human psyche has great concerns with philosophical-metaphysical aspect of human psyche so is not purely psychological. Besides, it is also remarkable to note that human nature in Ghazalian discourse emphasized on making profound analysis of the self, with its roles, its purpose, and the internal and external factors that cause its sorrows and pleasures. Thus, the present study recommends that although Freudian psychoanalytic theory has provided insightful psychological interpretations, equally appropriate readings result from analyzing Ghazalian theory of soul which balances the Freudian emphasis on the unconscious. This analytical approach may lead to an alternative critical agenda for the better understanding of human psyche. Besides, it is also anticipated that the understandings generated by this work may develop new insights in the realm of psychology.

CONCLUSION 
The Scholar Islamic Academic Research Journal

Vol. 6, No. 1 || January-June 2020 || P. 252-276

https://doi.org/10.29370/siarj/issue10ar18

From the above discussion, it can be concluded that though, in the West, important achievements have been made to explore the intricacies of human mind and behaviour, yet no single western model is truly allinclusive to provide understanding into the interaction between body, mind and soul, and the consequences of this interplay on human personality development. These major limitations in understanding human mind, raise the questions regarding the extent of human knowledge about self, and the depth of human understanding about personality. Even multiple Western ideologies seem to be inadequate because they neglect a dimension of the self that is vital to being human, i.e., the spiritual dimension.

Though, Ghazalian theory of soul and Freudian psychoanalysis have developed in utterly different times and in dissimilar social, cultural, and religious frameworks as models of the individual human psyche, but they offer diverse possibilities for the growth and development of human mind. This interdisciplinary study, has established the fact about the similar functioning of human mind, despite the variations in environmental, social and religious backgrounds. The logic behind deep conceptual parallels in Ghazali and Freud, is the depth of their psychological experiences and insight into human consciousness.

\section{(1) (8)}

BY NC SA This work is licensed under a Creative Commons

Attribution-NonCommercial-ShareAlike 4.0 International (CC BY-NC-SA 4.0) 